doi: $10.2306 /$ scienceasia1513-1874.2012.38.141

\title{
Combined effect of seaweed (Sargassum wightii) and Bacillus thuringiensis var. israelensis on the coastal mosquito, Anopheles sundaicus, in Tamil Nadu, India
}

\author{
Kanagarajan Prasanna Kumar ${ }^{\mathrm{a}}$, Kadarkarai Murugan ${ }^{\mathrm{a}, *}$, Kalimuthu Kovendan $^{\mathrm{a}}$, \\ Arjunan Naresh Kumar ${ }^{\mathrm{a}}$, Jiang-Shiou Hwang ${ }^{\mathrm{b}}$, Donald R. Barnard ${ }^{\mathrm{c}}$ \\ a Department of Zoology, School of Life Sciences, Bharathiar University, Coimbatore-641 046, India \\ b Institute of Marine Biology, National Taiwan Ocean University, Keelung 20224, Taiwan \\ c USDA-ARS-CMAVE, Gainesville, Florida 32608, USA
}

*Corresponding author, e-mail: kmvvk@yahoo.com

Received 16 May 2010

Accepted 22 May 2012

\begin{abstract}
Laboratory studies were made to determine the effectiveness of seaweed (Sargassum wightii) extract combined with Bacillus thuringiensis var. israelensis for the control of Anopheles sundaicus Liston, a malaria vector that occurs in the coastal areas of peninsular India. The results revealed that the different concentrations of crude extract of S. wightii resulted in considerable mortality and the $\mathrm{LC}_{50}$ value for I Instar larvae at $1.0 \mathrm{mg} / \mathrm{l}$ was 0.88 , for II Instar 0.73 , for III Instar 1.34, for IV Instar 1.56, and for pupa 1.71. The LC $_{90}$ values of I, II, III, and IV Instar, and pupa were $2.73,2.43,3.03,3.21$, and $3.23 \mathrm{mg} / \mathrm{ml}$, respectively. Among the larval instars, instar II was the most susceptible. A considerable repellency was noted; a $10 \mathrm{mg} / \mathrm{l}$ concentration of $S$. wightii showed a repellency of $89 \%$. Sea weed extract and B. thuringiensis toxins affected the larval duration and adult emergence. A synergistic factor was also found for the effect of seaweed extract against larvae and pupae of mosquito. The synergistic factor showed at I Instar was 1.74, II Instar was 1.93, III Instar was 1.37, IV Instar was 1.27, and pupa was 1.24, respectively. The result revealed that the seaweed extract of S. wightii in combination with microbial toxins has interfered in the gut system and resulted in mortality as well as growth inhibitory effects on mosquitoes.
\end{abstract}

KEYWORDS: larvicidal activity, repellency, vector control, malarial vector

\section{INTRODUCTION}

Mosquitoes are important blood sucking insects. They transmit disease agents that cause malaria, dengue, yellow fever, encephalitis, and filariasis. Human malaria occurs mainly in tropical and subtropical regions of the world and is caused by infection with Plasmodium falciparum, $P$. vivax, $P$. ovale, or P. malariae $^{1}$, which are transmitted to humans only by Anopheles mosquitoes.

Mosquito control is critical for managing the spread of disease agents they transmit and is based primarily on the use of conventional synthetic chemical insecticides. The effectiveness of these chemicals for vector control is diminished when mosquitoes develop resistance to the insecticide(s) ${ }^{2}$. Additionally, the use of synthetic chemical insecticides presents the potential for environmental pollution and some evidence suggests these materials act as immunosuppressants ${ }^{3}$.

Interest in alternatives to synthetic chemical insecticides for mosquito control has resulted in the evaluation of plant extracts with insecticidal activity. Advantages to the use of botanical insecticides include safety to humans and animals, rapid breakdown of the toxic molecules in the environment, and comparatively few adverse effects to nontarget organisms.

A number of extracts from terrestrial plants have been studied for toxicity to larvae of Anopheles mosquitoes, including those from Calophyllum inophyllum (Clusiaceae), Rhinacanthus nasutus (Acanthaceae), Solanum suratense (Solanaceae), Samadera indica (Simaroubaceae), and Myriophyllum spicatum (Haloragaceae) $^{4,5}$. Sargassum wightii Greville (Sargassaceae) is an abundant marine brown alga commonly found in the shorelines of India. It is a macroscopic, multicellular, photosynthetic, non vascular, pelagic marine species ${ }^{6}$ rich in sulphated polysaccharides that manifest potent free radical scavenging ${ }^{7}$ and antioxidant ${ }^{8}$ effects. These properties justify S. wightii investigations for searching biologically active compounds that may be useful in mosquito control and as alternatives to conventional synthetic 
insecticides.

Bacillus thuringiensis var. israelensis (Bti) is a naturally occurring bacterium that kills certain arthropod species. When ingested by a mosquito larva, the Bti parasporal body dissolves in the alkaline gut juices where midgut proteases cleave the protoxin yielding active $\delta$-endotoxin proteins. These endotoxins bind to specific receptors, disrupt the activity of midgut epithelial cell membranes, and damage the gut wall leading to rapid death from starvation ${ }^{9}$. This study aimed to determine the combined effect of Sargassum wightii extract and Bacillus thuringiensis var. israelensis as a mosquito larvicide and/or pupicide, as a regulator of growth in immature mosquitoes, and as a repellent to host seeking female Anopheles sundaicus Liston.

\section{MATERIALS AND METHODS}

\section{Collection of mosquito eggs, mosquito rearing, and blood feeding}

The eggs of A. sundaicus were collected (using an ' $\mathrm{O}$ ' type brush) from drinking water containers located in coastal areas of Velankanni $\left(79.8^{\circ} \mathrm{E}, 10.7^{\circ} \mathrm{N}\right)$, Nagapattinam $\left(79.8^{\circ} \mathrm{E}, 10.7^{\circ} \mathrm{N}\right)$, and Cuddalore $\left(79.4^{\circ} \mathrm{E}\right.$, $11.4^{\circ} \mathrm{N}$ ), Tamil Nadu, India. In the laboratory, eggs were transferred to $18 \mathrm{~cm} \mathrm{~L} \times 13 \mathrm{~cm} \mathrm{~W} \times 4 \mathrm{~cm} \mathrm{H}$ enamel trays containing $500 \mathrm{ml}$ of tap water. Larvae were reared at $27 \pm 2{ }^{\circ} \mathrm{C}, 75-85 \% \mathrm{RH}$, in a $14: 10$ (light:dark) photoperiod and fed ground dog biscuit and brewers yeast in a 3:1 ratio until pupation.

Pupae were collected from the rearing trays using a pipette and transferred to plastic containers $(12 \mathrm{~cm}$ $\mathrm{H} \times 12 \mathrm{~cm} \mathrm{D)}$ containing $500 \mathrm{ml}$ of water. Plastic containers with pupae were placed inside $90 \mathrm{~cm}$ $\mathrm{H} \times 90 \mathrm{~cm} \mathrm{~L} \times 90 \mathrm{~cm} \mathrm{~W}$ cages prior to emergence of the adult mosquitoes. Each cage consisted of a wooden frame covered with polythene on the sides, back, and top. Adults were allowed access to $10 \%$ sucrose solution ad libitum via cotton wick. Female mosquitoes were fed stored human blood using methods described ${ }^{10}$.

\section{Collection and extraction of $S$. wightii}

S. wightii was collected at the Gulf of Mannar Biosphere Reserve (GoMBR) on the SE coast of Tamil Nadu, India from an area between $8^{\circ} 49^{\prime} \mathrm{N}$ and $9^{\circ} 15^{\prime} \mathrm{N}$ and $78^{\circ} 11^{\prime} \mathrm{E}$ and $79^{\circ} 15^{\prime} \mathrm{E}$. Each specimen was washed with water and dried at room temperature. Dried material was ground into powder $(100-150 \mu \mathrm{m})$ using a blender. One hundred grams of the powder was extracted with $300 \mathrm{ml}$ of methanol for $8 \mathrm{~h}$ in a Soxhlet apparatus and the extract was dried in a rotary vacuum evaporator to yield $S$. wightii extract residue. One gram of the residue was dissolved in $100 \mathrm{ml}$ of acetone to make a $1 \%$ stock solution. Five different concentrations of the extract $(2,4,6,8$, and $10 \mathrm{mg} / \mathrm{l})$ were prepared from the stock solution for testing.

\section{Preparation of $B$. thuringiensis var. israelensis}

The Bti was obtained from T-Stanes \& Company Pvt. Limited, Coimbatore, India. Five concentrations, i.e., $0.25,0.50,1.0,1.5$, and $2.0 \%$, were prepared by diluting the original material with distilled water.

\section{Larval toxicity test of $S$. wightii}

Twenty-five I Instar, II Instar, III Instar, and IV Instar instars were placed in $249 \mathrm{ml}$ of dechlorinated water in separate $500 \mathrm{ml}$ glass beakers followed by the additional of $1 \mathrm{ml}$ of the desired concentration of S. wightii extract. Food (see before) was provided for larvae in each test. At five tested concentrations, 3 trials were made and each trial consisted of three replicates. In each test, the control comprised of $1 \mathrm{ml}$ of acetone mixed with $249 \mathrm{ml}$ of de-chlorinated water. Correction for control mortality was made using Abbott's formula ${ }^{11}$ : Mortality $=($ Number of dead larvae)/(Number of larvae introduced).

$\mathrm{LC}_{50}$ and $\mathrm{LC}_{90}$ were calculated from toxicity data by using probit analysis ${ }^{12}$.

\section{Pupal toxicity test of $S$. wightii}

A laboratory colony of mosquito pupae were used for pupicidal bioassay. Twenty freshly emerged pupae were kept in $500 \mathrm{ml}$ glass beaker containing $249 \mathrm{ml}$ of de-chlorinated water and $1 \mathrm{ml}$ of desired S. wightii concentration was added separately. Three replicates were set up for the five tested concentration and a control set up by mixing $1 \mathrm{ml}$ of de-chlorinated water. The control mortality was corrected by Abbot's formula ${ }^{11}$ : Mortality $=$ (Number of dead pupae)/(Number of pupae introduced).

$\mathrm{LC}_{50}$ and $\mathrm{LC}_{90}$ were calculated from toxicity data by using probit analysis ${ }^{12}$.

\section{Test for growth regulatory activity}

Methanolic extracts of $S$. wightii and Bti were tested for larval, pupal, and adult development activity against recently hatched I Instar A. sundaicus ${ }^{13}$. The test of $S$. wightii for development activity was drawn at five different concentrations ranging from $1-10 \mathrm{mg} / \mathrm{l}$, Bti from $0.25-2 \mathrm{mg} / \mathrm{l}$, and the desired concentration of the test solution achieved by adding $1.0 \mathrm{ml}$ of an appropriate stock solution to $249 \mathrm{ml}$ of dechlorinated water. Three replicates for each concentration were set up. All larvae were monitored to adult emergence 
Table 1 Combined effect of methanolic extract of Sargassum wightii Greville and microbial insecticide, Bacillus thuringiensis var. israelensis at various concentrations on larvicidal and pupicidal activity against coastal malarial vector, Anopheles sundaicus.

\begin{tabular}{|c|c|c|c|c|c|c|c|c|}
\hline \multirow{3}{*}{$\begin{array}{l}\text { Larval \& } \\
\text { pupal } \\
\text { stages }\end{array}$} & \multicolumn{5}{|c|}{ Larval and pupal mortality (\%) } & \multirow{3}{*}{$\begin{array}{c}\text { Value of } \\
\text { LC }_{50}(\%) \\
(\mathrm{LCL}-\mathrm{UCL})\end{array}$} & \multirow{3}{*}{$\begin{array}{c}\text { Value of } \\
\mathrm{LC}_{90}(\%) \\
(\mathrm{LCL}-\mathrm{UCL})\end{array}$} & \multirow{3}{*}{$\begin{array}{c}\text { Chi-square } \\
\text { value } \\
\left(\chi^{2}\right)\end{array}$} \\
\hline & \multicolumn{5}{|c|}{ Combined concentration of $S$. wightii and Bti $(\mathrm{mg} / \mathrm{l})$} & & & \\
\hline & $2.00+0.25$ & $2.00+0.50$ & $2.00+1.00$ & $2.00+1.50$ & $2.00+2.00$ & & & \\
\hline I & $29^{\mathrm{b}}$ & $43^{\mathrm{ab}}$ & $58^{\mathrm{ab}}$ & $62^{\mathrm{ab}}$ & $79^{\mathrm{b}}$ & $\begin{array}{c}0.88 \\
(0.69-1.04)\end{array}$ & $\begin{array}{c}2.73 \\
(2.34-3.37)\end{array}$ & 3.137 \\
\hline II & $34^{\mathrm{a}}$ & $45^{\mathrm{a}}$ & $60^{\mathrm{a}}$ & $69^{\mathrm{a}}$ & $84^{\mathrm{a}}$ & $\begin{array}{c}0.73 \\
(0.54-0.89)\end{array}$ & $\begin{array}{c}2.43 \\
(2.11-2.94)\end{array}$ & 0.933 \\
\hline III & $20^{\mathrm{c}}$ & $28^{\mathrm{b}}$ & $39^{\mathrm{b}}$ & $54^{\mathrm{b}}$ & $70^{\mathrm{c}}$ & $\begin{array}{c}1.34 \\
(1.18-1.52)\end{array}$ & $\begin{array}{c}3.03 \\
(2.63-3.68)\end{array}$ & 0.261 \\
\hline IV & $14^{\mathrm{d}}$ & $22^{\mathrm{c}}$ & $34^{\mathrm{c}}$ & $46^{\mathrm{d}}$ & $64^{\mathrm{d}}$ & $\begin{array}{c}1.56 \\
(1.40-1.78)\end{array}$ & $\begin{array}{c}3.21 \\
(2.78-3.90)\end{array}$ & 0.523 \\
\hline Pupa & $9^{c}$ & $17^{\mathrm{c}}$ & $28^{\mathrm{d}}$ & $39^{\mathrm{e}}$ & $59^{\mathrm{e}}$ & $\begin{array}{c}1.71 \\
(1.52-1.99)\end{array}$ & $\begin{array}{c}3.23 \\
(2.78-3.94)\end{array}$ & 0.612 \\
\hline
\end{tabular}

Within column means followed by the same letter(s) are not significantly different at $5 \%$ level by DMRT.

and were provided with larval food. Observations were made at $24 \mathrm{~h}$ intervals and the dead larvae and pupae were removed daily and counted. The development stages of larvae, pupae, and adults were monitored. The percentage of total emergence at different concentration was recorded. The emergence inhibition concentrations $\left(\mathrm{EI}_{50}\right.$ and $\left.\mathrm{EI}_{90}\right)$ were derived from the experimental data through probit analysis ${ }^{12}$.

\section{Combined activity}

The methanolic activity of $S$. wightii was studied for the combined effect with Bti at five different concentrations ranging from $0.25-2 \mathrm{mg} / \mathrm{l}(0.25,0.50,1.00$, $1.50,2.00)$. A control was set up (in each test) with $1 \mathrm{ml}$ of acetone and $249 \mathrm{ml}$ of dechlorinated water. The synergistic factor was calculated from $\mathrm{LC}_{50}$ value of microbial insecticide alone divided by the $\mathrm{LC}_{50}$ value of the algae extract. A synergistic factor (SF) greater than one is considered to be synergism, an SF value less than one is considered to be antagonism: Synergistic Factor $=($ LC value of microbial insecticide)/(LC value of plant extract with insecticide).

\section{Repellent activity of $S$. wightii}

Repellent activity of plant compounds tested with human volunteers. For the repellent activity of $S$. wightii percentage protection in relation to dose method was adopted $^{14}$. Three to four day old blood starved female of adult mosquitoes (100) were kept in a net cage. The arms of the test person was cleaned with disinfectant isopropanol. After air-drying the arm only $25 \mathrm{~cm}^{2}$ of the dorsal side of the skin on each lower arm was exposed, the remaining area being covered by rubber gloves. The $S$. wightii was dissolved in isopropanol and this alcohol served as a control. The extracts S. wightii at 2, 4, 6, 8, $10 \mathrm{mg} / \mathrm{l}$ concentrations was applied. The control and treated arms were introduced separately into the cage, the number of bites counted over $5 \mathrm{~min}$ every $60 \mathrm{~min}$, from $5.00-10.00 \mathrm{~h}$. The experiment was conducted five times. The percentage of protection (post treatment) was calculated by using the following formula ${ }^{4}$ : Protection $=$ (Number of bites received by control arm - Number of bites received by treated arm)/(Number of bites received by control arm).

\section{STATISTICAL ANALYSIS}

The data from the bioassay were subject to statistical analysis. The SPSS software package was used for computing all the data including probit analysis, correlation co-efficient, and mean of the sample.

\section{RESULTS}

Table 1 illustrates the combined effect of methanolic extracts of $S$. wightii and microbial insecticide, $B$. thuringiensis against all the larval instars and pupae of A. sundaicus. A $S$. wightii weed extract concentration $2 \mathrm{mg} / \mathrm{l}$ was constantly added with different Bti concentrations in the range of $0.25-2 \mathrm{mg} / \mathrm{l}$. A $79 \%$ mortality was observed at $2 \mathrm{mg} / \mathrm{l}$ in I Instar larva, whereas II, III, IV Instar larvae, and pupae showed 84, 70, 64, and 59\% mortality after the same treatment. The $\mathrm{LC}_{50}$ value of I, II, II, IV Instar, and pupa were $0.88 \%, 0.73 \%, 1.34 \%, 1.56 \%$, and $1.71 \%$, respectively. The $\mathrm{LC}_{90}$ value of I, II, III, IV Instar, and pupa were $2.73 \%, 2.43 \%, 3.03 \%, 3.21 \%$, and $3.23 \%$, 
Table 2 Combined effect of methanolic extract of Sargassum wightii Greville and microbial insecticide, Bacillus thuringiensis var. israelensis at various concentrations on the growth and development against Coastal Malarial vector, Anopheles sundaicus.

\begin{tabular}{|c|c|c|c|c|c|c|c|c|}
\hline \multirow{3}{*}{$\begin{array}{l}\text { Concentration } \\
\text { of } S . \text { wightii } \\
+B t i(\mathrm{mg} / \mathrm{l})\end{array}$} & \multicolumn{5}{|c|}{ Mean duration in each instars (days) ${ }^{\dagger}$} & \multirow{3}{*}{$\begin{array}{l}\text { Total } \\
\text { number } \\
\text { of days }\end{array}$} & \multirow{3}{*}{$\begin{array}{c}\text { Total } \\
\text { mortality } \\
(\%)\end{array}$} & \multirow{3}{*}{$\begin{array}{c}\text { Total } \\
\text { emergence } \\
(\%)\end{array}$} \\
\hline & $\mathrm{L}_{1}-\mathrm{L}_{2}^{\ddagger}$ & $\mathrm{L}_{2}-\mathrm{L}_{3}{ }^{\ddagger}$ & $\mathrm{L}_{3}-\mathrm{L}_{4} \neq$ & Pupae & Adult & & & \\
\hline & & & & & & & & \\
\hline $2.00+0.25$ & $1.0 \pm 0.4^{\mathrm{c}}$ & $0 \pm 0.6^{\circ}$ & $5.0 \pm 1.2^{\mathrm{b}}$ & $2.0 \pm 1.6^{\prime \prime}$ & $2.0 \pm 1.0^{\mathrm{a}}$ & $13.0 \pm 0.3^{3}$ & $6^{\mathrm{e}}$ & $94^{\mathrm{ab}}$ \\
\hline $2.00+0.50$ & $2.0 \pm 0.4^{\mathrm{b}}$ & $3.0 \pm 0.4^{\mathrm{b}}$ & $5.0 \pm 2.0^{\mathrm{b}}$ & $2.0 \pm 0.8^{\mathrm{a}}$ & $2.0 \pm 1.0^{\mathrm{a}}$ & $14.0 \pm 1.0^{\mathrm{c}}$ & $11^{\mathrm{d}}$ & $89^{\mathrm{b}}$ \\
\hline $2.00+1.00$ & $2.0 \pm 0.8^{\mathrm{b}}$ & $3.0 \pm 0.6^{\mathrm{b}}$ & $5.0 \pm 1.2^{\mathrm{b}}$ & $2.0 \pm 1.2^{\mathrm{a}}$ & $2.0 \pm 1.2^{\mathrm{a}}$ & $14.0 \pm 1.0^{\mathrm{c}}$ & $23^{\mathrm{c}}$ & $77^{\mathrm{c}}$ \\
\hline $2.00+1.50$ & $3.2 \pm 0.8^{\mathrm{a}}$ & $4.0 \pm 0.8^{\mathrm{a}}$ & $6.0 \pm 1.2^{\mathrm{a}}$ & $2.0 \pm 1.6^{\mathrm{a}}$ & $2.0 \pm 1.0^{\mathrm{a}}$ & $17.2 \pm 0.4^{\mathrm{a}}$ & $32^{\mathrm{b}}$ & $68^{\mathrm{d}}$ \\
\hline $2.00+2.00$ & $2.00 \pm 0.18^{\mathrm{b}}$ & $4.0 \pm 1.8^{\mathrm{a}}$ & $5.0 \pm 1.0^{\mathrm{b}}$ & $2.0 \pm 2.0^{\mathrm{a}}$ & $2.0 \pm 0.6^{\mathrm{a}}$ & $11.5 \pm 0.4^{\mathrm{e}}$ & $46^{\mathrm{a}}$ & $54^{\mathrm{e}}$ \\
\hline Control & $1.0 \pm 0.4^{\mathrm{c}}$ & $3.0 \pm 0.6^{\mathrm{b}}$ & $4.0 \pm 1.2^{\mathrm{c}}$ & $2.0 \pm 1.2^{\mathrm{a}}$ & $1.5 \pm 0.6^{\mathrm{b}}$ & $11.5 \pm 0.4^{\mathrm{e}}$ & $5^{\mathrm{e}}$ & $95^{\mathrm{a}}$ \\
\hline
\end{tabular}

Within column means followed by the same letter(s) are not significantly different at $5 \%$ level by DMRT.

Values $\pm \mathrm{SE}$

$\mathrm{L}_{1}, \mathrm{~L}_{2}, \mathrm{~L}_{3}, \mathrm{~L}_{4}$ : Larval stages

respectively. Among the different larval and pupal stages, the II Instar larvae were more susceptible than the other larval or pupal stages.

Table 2 provides the combined effect of methanolic extract of $S$. wightii and microbial insecticide, Bti at various concentrations on the growth and development of A. sundaicus larvae. The S. wightii weed extract concentration $2 \mathrm{mg} / \mathrm{l}$ is constantly added with different $B t i$ concentrations ranging from $0.25-2 \mathrm{mg} / \mathrm{l}$. Days of development were $11.5 \pm 0.4$ and the percentage of emergence was $95 \%$ at control. At $0.25 \mathrm{mg} / \mathrm{l}$ and $0.5 \mathrm{mg} / \mathrm{l} \mathrm{Bti}$ concentration, days of development were $13.0 \pm 0.3$ and $14.0 \pm 1.0$ and the rates of emergence were $94 \%$ and $89 \%$, respectively. At the concentrations of $1.00 \mathrm{mg} / \mathrm{l}$ and $1.50 \mathrm{mg} / \mathrm{l} \mathrm{Bti}$ the total days of development were $14.0 \pm 1.0$ and $17.2 \pm 0.4$ and the rate of total emergence was $77 \%$ and $68 \%$, respectively. The $\mathrm{EI}_{50}$ and $\mathrm{EI}_{90}$ values were 2.6 and $4.4 \%$. Among the different concentrations $2.0 \mathrm{mg} / \mathrm{l}$ was more effective than the other concentrations in the total emergence of adults.

Table 3 illustrates repellent activity $S$. wightii on malarial vector, A. sundaicus. At $2 \mathrm{mg} / \mathrm{l}$ concentration the repellent activity was $26 \%$ and at $10 \mathrm{mg} / \mathrm{l}$ concentration the percentage of repellency was $89 \%$.

The synergistic factor of methanolic extracts of marine sea weed $S$. wightii with microbial insecticide Bti for I, II, III, IV Instar larva, and pupa were: 1.74, $1.93,1.37,1.27$, and 1.24 , respectively. The higher synergistic value was on II Instar larvae. This may be due to the action of plant compounds from S. wightii (dioctyl phthalate) might have interacted with Bt cry toxins from the $B$. thuringiensis and brought out such a toxicity against different larval and pupal populations of A. sundaicus.
Table 3 Repellent activity Sargassum wightii Greville on malarial vector, Anopheles sundaicus Liston.

\begin{tabular}{lrrrrrr}
\hline Repellent & \multicolumn{5}{c}{ Number of mosquitoes fed } \\
\cline { 2 - 7 } $\begin{array}{l}\text { activity } \\
\text { observation (h) }\end{array}$ & Control & \multicolumn{5}{c}{ Concentration of S. wightii (mg/l) } \\
\cline { 2 - 7 } & & 2 & 4 & 6 & 8 & 10 \\
\hline $5.00-6.00 \mathrm{pm}$ & 25 & 20 & 16 & 12 & 7 & 3 \\
$6.00-7.00 \mathrm{pm}$ & 20 & 17 & 12 & 9 & 5 & 2 \\
$7.00-8.00 \mathrm{pm}$ & 16 & 11 & 10 & 7 & 4 & 2 \\
$8.00-9.00 \mathrm{pm}$ & 13 & 8 & 7 & 5 & 3 & 1 \\
$9.00-10.00 \mathrm{pm}$ & 10 & 6 & 5 & 3 & 2 & 1 \\
Fed mosquitoes & 84 & 62 & 41 & 30 & 17 & 9 \\
Unfed mosquitoes & 16 & 44 & 50 & 64 & 79 & 91 \\
Protection (\%) & & 26 & 40 & 57 & 71 & 89 \\
\hline
\end{tabular}

\section{DISCUSSION}

Most of the plant based products are not as effective as their synthetic counterparts, and to use mosquito control in a large scale programme under epidemic conditions may not be acceptable. However, the use of indigenous plant based products by individuals and communities can provide prophylactic measures for protection against various mosquito- borne diseases. In the present study, after the treatment of seaweed extract had considerable mortality against different larval instars of $A$. sundaicus. The plant chemicals might have dissolved in the water media and brought out such mortality to the larvae.

Earlier, several authors ${ }^{5,15,16}$ made an attempt to use plant extracts (Azadirachta indica, Ocimum sanctum, Albizzia amara, and Toddalia asiatica) against different An. stephensi and Aedes aegypti. After the exposure of plant extracts the percentage of repellency was increased and it may have been due to the volatile compounds.

There were numerous reports on mosquito lar- 
vicidal activity of terrestrial plants. We report here the first study on mosquito larvicidal and repellent activity of marine plants subsequently the mosquito larvicidal activity of seaweeds, Plocamium telfairiae and Laurencia nipponica ${ }^{17-21}$. Laboratory evaluation of traditionally used plant-based insect repellents against the malaria vector, Anopheles arabiensis Patton (Diptera: Culicidae). Ref. 22 reported that the alkaloid derived from the tropical vine Triphyophyllum peltatum was found to have larvicidal activity against the malarial vector, A. stephensi. Ref. 23 reported that the different age of eggs of $A$. stephensi treated with different concentrations of leaf extracts caused ovicidal activity resulting in failure to hatch the eggs. Ref. 15 reported the larvae hatched from the treated eggs showed much higher levels of mortality in all the treatments. Furthermore, plant-based repellent products are inexpensive, easily available, locally known, and culturally acceptable ${ }^{24,25}$, this finding would be useful in the field of mosquito control without polluting the environment. However, Ref. 26 showed that the skin repellent test at concentrations of 1.0, 2.5, and $5.0 \mathrm{mg} / \mathrm{cm}^{2}$ of $C$. citratus essential oil against the filarial mosquito Culex quinquefasciatus gave $100 \%$ protection up to $3.00,4.00$, and $5.00 \mathrm{~h}$, respectively.

The total percentage of protection of this essential oil was $50 \%$ at $1.0 \mathrm{mg} / \mathrm{cm}^{2}, 62 \%$ at $2.5 \mathrm{mg} / \mathrm{cm}^{2}$, and $74 \%$ at $5.0 \mathrm{mg} / \mathrm{cm}^{2}$ for $12 \mathrm{~h}$. In the present study, C. citratus extract established higher repellent activity against $A$. arabiensis even at the lower concentration. Effective repellent compounds, like dimethyl phthalate, available in the market are very costly and moreover they can give protection only for a short period of $1-2 \mathrm{~h}^{27}$.

The synergistic factor has been worked out and higher synergism was found to be on fourth instar larvae rather than other larval instars. Earlier investigations used the seaweeds Caulerpa scalpelliformis and Dictyota dichotoma and mangrove Rhizophora apiculata extracted in acetone, combined with synthetic insecticides (DDT, BHC, $\mathrm{HCH}$, and malathion), and evaluated for activity against fourth instar larvae of Aedes aegypti and the higher synergistic activity with all three insecticides, especially $\mathrm{HCH}^{28}$.

In the present study, S. wightii frond extract treatment resulted in higher larval and pupal mortality which might be due to the multiple actions of dioctyl phthalate and other bioactive compounds present in the weed. A similar study reported the evaluation of the use of Parthenium hysterphourus against mosquito ${ }^{29}$ and combined effect of other phenolic acids such a caffeic acid, vanillic acid, ansic acid, $p$-ansic acid, chlorogenic acid and parahydroxy benzoic acid may possess larvicidal and pupicidal property on A. aegypti and C. quinquefasciatus. In the present study, the exposure to plant extracts had a repellency effect against adult mosquito, and the presence of volatile compounds may be responsible for such effect ${ }^{2}$. Vineetha and Murugan ${ }^{16}$ had also worked out the repellent effect of Toddalia asiatica against the dengue vector, A. aegypti. It is now well understood that a mixture of functionally diverse toxins proves more effective than a single one and also causes delay in the development of resistance in targeted insects ${ }^{1,5}$.

The applications of Bti combined with plant extracts produced a high mortality of the target organism. Spore forming bacteria are able to be mass produced, stored, easily transported and applied. Their larvicidal activity is due to large amounts of crystal proteins produced during sporulation and transformed into toxins under specific conditions after ingestion by larvae of certain insect species. Their selectivity is determined by both the structure of the proteins produced by the bacterium strain and the presence of proteolytic enzymes and receptor in the host larvae midgut. Moreover, the active compounds in the $S$. wightii might interact with Bt toxins crystals and increased the toxicity against mosquito larvae. In view of the above, the synergistic interaction of plant compounds from $S$. wightii and microbial cry toxins from B. thuringiensis showed toxicity and biological effects on the larvae and adults of malarial vector, A. sundaicus. Biopesticides are not only used as mosquito vector control program, but also permit the maintenance of traditional knowledge for the benefit of communities. Hence the exploitation of plant chemicals and microbial pesticides are not only used as mosquito vector control program, but it can also be used for the control of mosquito-transmitted diseases. Moreover, adopting this kind of strategy would enable us to use pesticides that are safe for the environment in the future.

\section{REFERENCES}

1. Mueller I, Zimmerman PA, Reeder JC (2007) Plasmodium malariae and Plasmodium ovale-the 'bashful' malaria parasites. Trends Parasitol 23, 278-83.

2. Tabashnik BE, Finson N, Johnson MW (1991) Managing resistance to Bacillus thuringiensis: Lessons from the Diamond back Moth Lepidoptera: Plutellidae). $J$ Econ Entomol 24, 49-55.

3. Sengottayan Senthil Nathan (2007) The use of Eucalyptus tereticornis Sm. (Myrtaceae) oil (leaf extract) as a natural larvicidal agent against the malaria vector Anopheles stephensi Liston (Diptera: Culicidae). Bioresour Tech 98, 1856-60. 
4. Pushpanathan T, Jebanesan A, Govindarajan M (2006) Larvicidal, ovicidal and repellent activities of Cymbopogan citratus Stapf (Graminae) essential oil against the filarial mosquito Culex quinquefasciatus (Say) Diptera: Culicidae. Trop Biomed 23, 208-12.

5. Subramonia Thangam T, Kathiresan K (1991) Mosquito larvicidal activity of mangrove plant extracts against Aedes aegypti. Int Pest Contr 34, 116-9.

6. Sumich JL, Morrissey JF (2004) Introduction to the Biology of Marine Life, 8th edn, Jones and Bartlett Publishers, Sadbury.

7. Park PJ, Heo SJ, Park EJ, Kim SK, Byun HG, Jeon BT, Jeon YJ (2005) Reactive oxygen scavenging effect of enzymatic extracts from Sargassum thunbergii. J Agr Food Chem 53, 6666-72.

8. Xue C-H, Fang Y, Lin H, Chen L, Li Z-J, Deng D, Lu C-X (2001) Chemical characters and antioxidative properties of sulfated polysaccharides from Laminaria japonica. J Appl Phycol 13, 67-70.

9. Boisvert M, Boisvert J (2000) Effects of Bacillus thuringiensis var. israelensis on target and nontarget organisms: a review of laboratory and field experiments. Ann Bioeth 10, 517-61.

10. Meola R, Readio J (1987) Juvenile hormone regulation of the second biting cycle in Culex pipiens. J Insect Physiol 33, 751-4.

11. Abbott WS (1925) A method of computing the effectiveness of insecticides. J Econ Entomol 18, 265-7.

12. Finney DJ (1971) Probit Analysis. Cambridge Univ Press, London, pp 68-78.

13. Amalraj D, Vasuki V, Kalyanasundaram M, Tyagi BK, Das PK (1988) Laboratory and field evalution of three insect growth regulators against mosquito vectors. Indian J Med Res 97, 24-31.

14. Murugan K, Thangamathi P, Jeyabalan D (2002) Interactive effect of botanicals and Bacillus thuringiensis subsp. israelensis on Culex quinquefasciatus Say. J Sci Ind Res 61, 1068-76.

15. Murugan K, Jeyabalan D (1999) Mosquitocidal effect of certain plants extracts on Anophels stephensi. Curr Sci 76, 631-3.

16. Vineetha A, Murugan K (2009) Larvicidal and smoke repellency effect of Toddalia asiatica and Aegle marmelos against the dengue vector, Aedes aegypti (Insecta: Diptera: Culicidae). Entomol Res 39, 61-5.

17. World Health Organization (2005) Department of Control, Prevention and Eradication, Programme on Communicable Diseases, WHO Pesticide Evaluation Scheme (WHOPES); WHO: Geneva, Switzerland, WHO/CDS/WHOPES/GCDPP/2005.

18. Watanabe K, Umeda K, Miyakado M (1989) Isolation and identification of three insecticidal principles from the red alga Laurencia nipponica Yamada. Agr Biol Chem 53, 2513-5.

19. Watanabe K, Miyakado M, Ohono N, Okada A, Yanagi K, Moriguchi K (1989) A polyhalogenated insecticidal monoterpene from the red alga, Plocamitrm telfairiae.
Phytochemistry 8, 77-8.

20. Karunamoorthi K, Ilango K, Murugan K (2010) Laboratory evaluation of traditionally used plant-based insect repellent against the malaria vector Anopheles arabiensis Patton (Diptera: Culicidae). Parasitol Res 106, 1217-23.

21. Karunamoorthi K, Ilango K, Endale A (2009) Ethnobotanical survey of knowledge and usage custom of traditional insect/mosquito repellent plants among the Ethiopian Oromo ethnic group. J Ethnopharmacol 125, 224-9.

22. Govindarajan M, Jebanesan A, Pushpanathan T (2007) Larvicidal and ovicidal activity of Cassia fistula Linn. leaf extract against filarial and malarial vector mosquitoes. Parasitol Res 102, 289-92.

23. Govindarajan M, Jebanesan A, Pushpanathan T, Samidurai K (2008) Studies on effect of Acalypha indica $\mathrm{L}$. (Euphorbiaceae) leaf extracts on the malarial vector, Anopheles stephensi Liston (Diptera: Culicidae). Parasitol Res 103, 691-5.

24. Karunamoorthi K, Mulelam A, Wassie F (2008) Laboratory evaluation of traditional insect/mosquito repellent plants against Anopheles arabiensis, the predominant malaria vector in Ethiopia. Parasitol Res 103, 529-34.

25. Karunamoorthi K, Ramanujam S, Rathinasamy R (2008) Evaluation of leaf extracts of Vitex negundo L. (Family: Verbenaceae) against larvae of Culex tritaeniorhynchus and repellent activity on adult vector mosquitoes. Parasitol Res 103, 545-50.

26. Pushpanathan T, Jebanesan A, Govindarajan M (2008) The essential oil of Zingiber officinalis Linn (Zingiberaceae) as a mosquito larvicidal and repellent agent against the filarial vector Culex quinquefasciatus (Say) (Diptera: Culicidae). Parasitol Res 102, 1289-91.

27. Kalyanasundaram M, Amalraj D, Paily KP, Nisha George Sujatha CH (1986) Synthesis of substituted amides for repellency against mosquitoes. Curr Sci $\mathbf{5 5}$, 266-8.

28. Service MW (1983) Management of vector. In: Youdeowei A, Service N (eds) Pest and Vector Management in the Tropics. Longman group Ltd, England, pp 7-20.

29. Muthukrishnan J, Pushpalatha E (2001) Effects of plant extracts on fecundity and fertility of mosquitoes. J Appl Entomol 125, 31-5. 